\title{
Horticultural Science
}

http:/www.journals.zu.edu.eg/journalDisplay.aspx?Journalld=1\&queryType=Master

\section{EFFECT OF SOME ACTIVE MODIFIED ATMOSPHERE TREATMENTS ON QUALITY OF TOMATO (Solanum lycopersicum L.) FRUITS DURING COLD STORAGE AND SHELF LIFE PERIODS}

\author{
Asem A.S.A. Hassan", H.M.E. Arisha, A. Bardisi and Sabreen Kh.A. Ibraheim \\ Hort. Dept., Fac. Agric., Zagazig Univ., Egypt
}

Received: 21/2/2017 ; Accepted: 20/3/2017

\begin{abstract}
In 2014 and 2015 growing seasons, tomato seedlings cv. Alisa were transplanted on $15^{\text {th }}$ February and $6^{\text {th }}$ March and harvested on $13^{\text {th }}$ May and $25^{\text {th }}$ May, respectively in a private farm, Belbeis district, Sharkia Governorate, Egypt and subjected to the following post-harvest treatments in Post-harvest Laboratory, Hort. Dept. Fac. Agric., Zagazig University: 1) stored in open air (control); 2) stored in active modified atmosphere (AMA) with $3 \% \mathrm{O}_{2}+3 \% \mathrm{CO}_{2} ; 3$ ) AMA with $5 \% \mathrm{O}_{2}+3 \% \mathrm{CO}_{2}$; 4) AMA with 5\% $\mathrm{O}_{2}+5 \% \mathrm{CO}_{2}$ and 5) AMA with $7 \% \mathrm{O}_{2}+5 \% \mathrm{CO}_{2}$. Fruits of all treatments were stored for 35 days at $10 \pm 1^{\circ} \mathrm{C}$ and $90-95 \%$ relative humidity ( $\left.\mathrm{RH}\right)$. Samples of each treatment were randomly taken at 7 days intervals to evaluate the effect of cold storage periods and the tested (AMA) treatments on fruit quality. After each cold storage period, some of these fruits were kept for 5 days in both seasons under conditions of $20^{\circ} \mathrm{C}$ and $60-70 \%$ RH to detect the effect of treatments on shelf life. The tested active modified atmosphere (AMA) treatments tended to increase fruit firmness and vitam. C content as compared with the control during both cold storage and shelf life periods. On the contrary, AMA treatments tended to decrease fruit weight losses, fruit decay, TSS and lycopene content during both cold storage and shelf life periods. The advance of storage period from zero up to 35 days caused progressive increments in fresh weight losses, fruit decay, lycopene and TSS content of the successive samples which taken during cold storage and shelf life as compared with the control. On the contrary, the advance in cold storage period depressed fruit firmness and fruit ascorbic acid contents.
\end{abstract}

Key words: Tomato, active modified atmosphere, cold storage, shelf life, fruit quality.

\section{INTRODUCTION}

Tomato (Solanum lycopersicum L.) is one of the most widely cultivated and extensively consumed horticultural crops globally (Chapagain and Wiesman, 2004; Grandillo et al., 1999). The world's total tomato production is 113.3 million tons; China is the largest producer followed by the USA, Turkey, Italy, Egypt and India (Alam and Goyal, 2007). Tomato contains essential as well as beneficial components like carbohydrates, fiber, minerals, protein, fat, glycoalkaloids, phytosterols etc. (Davies et al., 1981). Several essential vitamins like vitamin A, vitamin $C$, vitamin $\mathrm{E}$, folic acid and several water-soluble vitamins are also present in tomato fruits
(Beecher, 1998). According to Brandt et al. (2006) it has been reported that the consumption of tomatoes reduces the risk of atherosclerosis, carcinogenesis and cardiovascular diseases and prevention of many types of cancer.

Losses in fresh horticultural produce are directly related to quality degradation. Quality loss is the result of improper handling and transportation in marketable of produce (Kumar et al., 2015). Tomato is one of the very perishable fruit and it changes continuously after harvesting. Depending on the humidity and temperature it ripens very soon, ultimately resulted in poor quality as the fruit become soft and unacceptable (Ullah, 2009).

\footnotetext{
${ }^{*}$ Corresponding author: Tel. : +201027547143

E-mail address: asem2000_3000@yahoo.com
} 
Storage under low temperature has been considered the most efficient method to maintain quality of most fruits and vegetables due to its effects on reducing respiration rate, transpiration, ethylene production, ripening, senescence and rot development (Hardenburg et al., 1986). Extending the shelf life of tomatoes is very important for domestic and export marketing. Generally, shelf life of tomatoes is extended by refrigerated storage (Risse et al., 1985).

Tomato fruits kept within sealed packages resulted in an atmosphere with high $\mathrm{CO}_{2}$ and low $\mathrm{O}_{2}$ content. These conditions retained flesh firmness, low acidity and soluble solids concentration and delayed fruit lycopene (Saeed et al., 2010). Among the various techniques developed to extend fruit postharvest life, is the use of plastic film. Rosa (2006) stated that LDPE (low density polyethylene) film is generally used for the packaging of fresh fruits and vegetables, owing to its high permeability and softness when compared to HDPE (high density polyethylene) film.

Information about the effect of active modified atmosphere (AMA) packing on shelf life of tomato fruit is limited; therefore, this research was conducted to evaluate the effect of storage under active modified atmosphere (AMA) condition on shelf life and quality of tomato fruits.

\section{MATERIALS AND METHODS}

This study was carried out during 2014 and 2015 seasons on tomato fruits (Solanum lycopersicum L.) cv. Alisa. The plants were transplanted in a private farm, Belbeis district, Sharkia Governorate, and received the standard horticultural care adapted in the area. Tomato fruits were harvested at pink stage (red color 30$60 \%$ of the total surface area) according to USDA, (1991). Fruits were packed in carton boxes and transported directly to Post-Harvest Laboratory in Hort. Dept., Fac. Agric., Zagazig University. Fruits with any insect infestation or defects (sunburn, crack, bruise and cuts) were discarded. All fruits were dipped in aqueous solution of $0.1 \%$ imazalil for 2 minutes according to Spalding, (1980) as a disinfectant, then, air dried. A final sorting was done to recheck the fruits for any defects which were not detected at first discarding.

The experiment was done to study the effect of active modified atmosphere (AMA) on physical and chemical properties of tomato fruits during cold storage for 35 days and shelf life for 5 days. This experiment was including 30 treatments which were the combinations between 5 AMA treatments and 6 storage periods as follows:

\section{Active Modified Atmosphere (AMA) Treatments}

1. Storing fruits in net at $10 \pm 1^{\circ} \mathrm{C}$ as control.

2. Storing fruits in sealed low density polyethylene (LDPE) bags contain $3 \% \mathrm{O}_{2}+$ $3 \% \mathrm{CO}_{2}$ at $10 \pm 1^{\circ} \mathrm{C}$.

3. Storing fruits in sealed LDPE bags contain $5 \% \mathrm{O}_{2}+3 \% \mathrm{CO}_{2}$ at $10 \pm 1{ }^{\circ} \mathrm{C}$.

4. Storing fruits in sealed LDPE bags contain $5 \% \mathrm{O}_{2}+5 \% \mathrm{CO}_{2}$ at $10 \pm 1{ }^{\circ} \mathrm{C}$.

5. Storing fruits in sealed LDPE bags contain $7 \% \mathrm{O}_{2}+5 \% \mathrm{CO}_{2}$ at $10 \pm 1{ }^{\circ} \mathrm{C}$.

\section{Storage Periods}

Ten tomato fruits (about $1 \mathrm{~kg}$ ) were placed in carton box covered with sealed low density polyethylene (LDPE) bags and injected with the previous gases and stored at $10 \pm 1{ }^{\circ} \mathrm{C}$. Then, observations samples were taken at 7 days intervals up to 35 days $(0,7,14,21,28$ and 35 days). After each cold storage period some of this fruits were subjected to conditions of $20^{\circ} \mathrm{C}$ and $60-70 \% \mathrm{RH}$ for 5 days as a shelf life. The number of fruits required for this experiment $=5$ AMA treatments $\times 6$ storing periods $\times 3$ reps. $\times$ 10 fruits per each replicate $=900$ fruits.

Samples of each treatment were randomly taken every 7 days intervals to evaluate the effect of AMA treatments; storing periods and their interactions on physical and chemical properties of tomato fruits during cold storage and shelf life periods. 


\section{Data Recorded}

\section{Fruit firmness $\left(\mathrm{kg} / \mathrm{cm}^{2}\right)$}

It was determined on five fruits per replicate and measurements were taken from each fruit using a Push Pull dynamometer (Model FD 101). The values were expressed as $\mathrm{kg} / \mathrm{cm}^{2}$.

\section{Weight loss (WL\%)}

The fruits were weighed before cold storage to obtain the initial weight and then weighed after each period of cold storage as well as after 5 days shelf life period. WL (\%) was calculated according to the following equation:

$$
W L(\%)=\frac{W i-W s}{W i} \times 100
$$

Where:

$\mathrm{Wi}=$ fruit weight at initial date.

$\mathrm{Ws}=$ fruit weight on day of sampling observation.

\section{Fruit decay percentage}

Decay of fruit was recorded as soon as fungal mycelia appeared on the calyx or peel of the fruit and it was calculated as a percent of the number of decayed fruits to the total number of fruits at each sampling date.

\section{Ascorbic acid (mg/100ml juice)}

It was determined by titration in the presence of 2, 6 dichlorophenol-indophenol dye as an indicator against $2 \%$ oxalic acid solution as substrate. Ascorbic acid was calculated as milligram L-ascorbic acid per $100 \mathrm{ml}$ of juice according to the method described by AOAC (2000).

\section{Lycopene content $(\mathrm{mg} / \mathbf{1 0 0 g}$ fresh fruit weight)}

It was determined according the method reported by Anthon and Barrett (2007).

\section{Juice (TSS Brix ${ }^{\circ}$ )}

It was determined using a hand refractometer.

\section{Statistical Analysis}

The treatments were arranged in split plot design with 3 replicates. AMA treatments were randomly arranged in the main plots and stored periods were randomly distributed in sub plots. The analysis of variance was calculated according to Snedecor and Cochran (1980). Means separation was done according to LSD at $0.05 \%$ level.

\section{RESULTS AND DISCUSSION}

\section{Fruit Firmness (FF) $\mathrm{kg} / \mathrm{cm}^{2}$}

\section{During cold storage periods}

Results in Table 1 reveal that the tested active modified atmosphere (AMA) treatments affected fruit firmness (FF) significantly in both tested seasons. As such, the highest FF values $\left(1.07\right.$ and $\left.0.96 \mathrm{~kg} / \mathrm{cm}^{2}\right)$ were recorded by $7 \%$ $\mathrm{O}_{2}+5 \% \mathrm{CO}_{2}$ in the first and second seasons, respectively, as compared with control (net), without significant differences with those treated by all other AMA treatments, i.e., $3 \% \mathrm{O}_{2}+3 \%$ $\mathrm{CO}_{2}, 5 \% \mathrm{O}_{2}+3 \% \mathrm{CO}_{2}$ and $5 \% \mathrm{O}_{2}+5 \% \mathrm{CO}_{2}$ in both tested seasons.

Moreover, FF values were significantly decreased with advancing cold storage periods in both seasons. As such, the highest FF values $\left(1.36\right.$ and $\left.1.17 \mathrm{~kg} / \mathrm{cm}^{2}\right)$ were recorded at initial sampling date (zero time) in the first and second seasons, respectively. While, the lowest FF values $\left(0.69\right.$ and $\left.0.75 \mathrm{~kg} / \mathrm{cm}^{2}\right)$ were recorded at 35 days cold storage, in the first and second seasons, respectively.

In addition, the interaction between the tested AMA treatments and cold storage periods was significant in the two tested seasons. As such, the highest FF values were recorded with all tested AMA treatments $\times$ zero time. While, the lowest $\mathrm{FF}$ values were recorded with all tested AMA treatments $\times 35$ days cold storage without significant differences between them in both seasons.

\section{During shelf life periods}

Results in Table 1 also show that values of FF during shelf life were significantly affected, 
Table 1. Effect of some active modified atmosphere (AMA) treatments on fruit firmness (FF $\mathrm{Kg} / \mathrm{cm}^{2}$ ) of tomato fruits $\mathrm{cv}$. Alisa during cold storage and shelf life periods during 2014 and 2015 seasons

\begin{tabular}{|c|c|c|c|c|c|c|c|c|}
\hline & & \multicolumn{7}{|c|}{ Firmness (FF Kg/cm $\left.{ }^{2}\right)$} \\
\hline \multirow{2}{*}{\multicolumn{2}{|c|}{ AMA treatment }} & \multicolumn{6}{|c|}{ Cold storage period (day) } & \multirow{2}{*}{$\underset{\text { (average) }}{\text { AMA }}$} \\
\hline & & $\mathbf{0}$ & 7 & 14 & 21 & 28 & 35 & \\
\hline \multirow{7}{*}{ 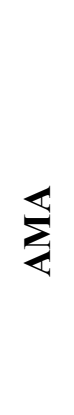 } & & \multicolumn{7}{|c|}{ First season (2014) } \\
\hline & Control(Net) & $1.29 \mathrm{ac}$ & $0.98 \mathrm{cg}$ & $0.90 \mathrm{di}$ & $0.83 \mathrm{ei}$ & $0.76 \mathrm{fi}$ & $0.65 \mathrm{gi}$ & $0.90 \mathrm{~B}$ \\
\hline & $3 \% \mathrm{O}_{2}+3 \% \mathrm{CO}_{2}$ & $1.30 \mathrm{ac}$ & $1.07 \mathrm{bf}$ & $1.05 \mathrm{bf}$ & $1.01 \mathrm{cf}$ & $0.96 \mathrm{ci}$ & $0.64 \mathrm{i}$ & $1.00 \mathrm{~A}$ \\
\hline & $5 \% \mathrm{O}_{2}+3 \% \mathrm{CO}_{2}$ & $1.44 \mathrm{a}$ & $1.04 \mathrm{bf}$ & $1.04 \mathrm{bf}$ & $0.98 \mathrm{ch}$ & $0.83 \mathrm{ei}$ & $0.78 \mathrm{fi}$ & $1.02 \mathrm{~A}$ \\
\hline & $5 \% \mathrm{O}_{2}+5 \% \mathrm{CO}_{2}$ & $1.43 \mathrm{a}$ & $1.12 \mathrm{ae}$ & $1.06 \mathrm{bf}$ & $1.04 \mathrm{bf}$ & $0.94 \mathrm{di}$ & $0.65 \mathrm{hi}$ & $1.04 \mathrm{~A}$ \\
\hline & $7 \% \mathrm{O}_{2}+5 \% \mathrm{CO}_{2}$ & $1.37 \mathrm{ab}$ & $1.23 \mathrm{ad}$ & $1.16 \mathrm{ae}$ & $1.08 \mathrm{bf}$ & $0.84 \mathrm{ei}$ & $0.76 \mathrm{fi}$ & $1.07 \mathrm{~A}$ \\
\hline & SP(average) & $1.36 \mathrm{~A}$ & $1.06 \mathrm{~B}$ & $1.04 \mathrm{~B}$ & $1.01 \mathrm{BC}$ & $0.86 \mathrm{C}$ & $0.69 \mathrm{D}$ & - \\
\hline \multicolumn{9}{|c|}{ Second season (2015) } \\
\hline \multirow{7}{*}{$\sum$} & Control(Net) & $1.13 \mathrm{ab}$ & $0.95 \mathrm{ce}$ & $0.90 \mathrm{df}$ & $0.85 \mathrm{eh}$ & $0.78 \mathrm{gj}$ & $0.71 \mathrm{j}$ & $0.88 \mathrm{~B}$ \\
\hline & $3 \% \mathrm{O}_{2}+3 \% \mathrm{CO}_{2}$ & $1.18 \mathrm{a}$ & $1.03 \mathrm{bc}$ & $0.95 \mathrm{ce}$ & $0.93 \mathrm{ce}$ & $0.84 \mathrm{ei}$ & $0.74 \mathrm{hj}$ & $0.94 \mathrm{~A}$ \\
\hline & $5 \% \mathrm{O}_{2}+3 \% \mathrm{CO}_{2}$ & $1.22 \mathrm{a}$ & $1.13 \mathrm{ab}$ & $0.97 \mathrm{~cd}$ & $0.88 \mathrm{dg}$ & $0.73 \mathrm{ij}$ & $0.78 f j$ & $0.95 \mathrm{~A}$ \\
\hline & $5 \% \mathrm{O}_{2}+5 \% \mathrm{CO}_{2}$ & $1.16 \mathrm{a}$ & $1.14 \mathrm{ab}$ & $0.93 \mathrm{ce}$ & $0.90 \mathrm{df}$ & $0.83 \mathrm{ei}$ & $0.76 \mathrm{gj}$ & $0.95 \mathrm{~A}$ \\
\hline & $7 \% \mathrm{O}_{2}+5 \% \mathrm{CO}_{2}$ & $1.16 \mathrm{a}$ & $1.11 \mathrm{ab}$ & $0.97 \mathrm{~cd}$ & 0.91 ce & $0.83 \mathrm{ei}$ & $0.78 \mathrm{fj}$ & $0.96 \mathrm{~A}$ \\
\hline & SP(average) & $1.17 \mathrm{~A}$ & $1.07 \mathrm{~B}$ & $0.94 \mathrm{C}$ & $0.89 \mathrm{C}$ & $0.80 \mathrm{D}$ & $0.75 \mathrm{D}$ & - \\
\hline & & \multicolumn{7}{|c|}{$\begin{array}{c}5 \text { days shelf life } \\
\text { First season (2014) }\end{array}$} \\
\hline \multirow{6}{*}{$\sum$} & Control(Net) & $0.96 a g$ & $0.83 \mathrm{bi}$ & $0.76 \mathrm{ek}$ & $0.70 \mathrm{fk}$ & $0.61 \mathrm{ik}$ & $0.50 \mathrm{k}$ & $0.72 \mathrm{~B}$ \\
\hline & $3 \% \mathrm{O}_{2}+3 \% \mathrm{CO}_{2}$ & $1.06 \mathrm{ad}$ & $0.92 \mathrm{ah}$ & 0.86ai & $0.82 \mathrm{cj}$ & $0.67 \mathrm{gk}$ & $0.53 \mathrm{jk}$ & $0.81 \mathrm{AB}$ \\
\hline & $5 \% \mathrm{O}_{2}+3 \% \mathrm{CO}_{2}$ & $1.12 \mathrm{ab}$ & $0.99 \mathrm{af}$ & 0.89ai & $0.80 \mathrm{dj}$ & $0.69 \mathrm{fk}$ & $0.60 \mathrm{ik}$ & $0.84 \mathrm{~A}$ \\
\hline & $5 \% \mathrm{O}_{2}+5 \% \mathrm{CO}_{2}$ & $1.11 \mathrm{ac}$ & $0.96 \mathrm{ag}$ & 0.87ai & $0.83 \mathrm{bi}$ & $0.75 \mathrm{ek}$ & $0.68 \mathrm{gk}$ & $0.86 \mathrm{~A}$ \\
\hline & $7 \% \mathrm{O}_{2}+5 \% \mathrm{CO}_{2}$ & $1.15 \mathrm{a}$ & $1.02 \mathrm{ae}$ & $0.93 \mathrm{ah}$ & $0.85 \mathrm{ai}$ & $0.74 \mathrm{ek}$ & $0.66 \mathrm{hk}$ & $0.89 \mathrm{~A}$ \\
\hline & SP (average) & $1.08 \mathrm{~A}$ & $0.94 \mathrm{AB}$ & $0.86 \mathrm{BC}$ & $0.80 \mathrm{CD}$ & 0.69DE & $0.59 \mathrm{E}$ & - \\
\hline \multicolumn{9}{|c|}{ Second season $(2015)$} \\
\hline \multirow{6}{*}{$\sum$} & Control(Net) & $0.98 \mathrm{ae}$ & $0.87 \mathrm{fi}$ & $0.83 \mathrm{gj}$ & $0.73 \mathrm{~km}$ & $0.68 \ln$ & $0.59 n$ & $0.78 \mathrm{~B}$ \\
\hline & $3 \% \mathrm{O}_{2}+3 \% \mathrm{CO}_{2}$ & $1.00 \mathrm{ad}$ & 0.89ai & $0.84 \mathrm{fj}$ & $0.80 \mathrm{ik}$ & $0.72 \mathrm{~km}$ & $0.61 \mathrm{n}$ & $0.81 \mathrm{AB}$ \\
\hline & $5 \% \mathrm{O}_{2}+3 \% \mathrm{CO}_{2}$ & $1.05 \mathrm{a}$ & $0.95 \mathrm{bf}$ & $0.87 \mathrm{fi}$ & $0.75 \mathrm{j} 1$ & $0.72 \mathrm{~km}$ & $0.58 n$ & $0.82 \mathrm{AB}$ \\
\hline & $5 \% \mathrm{O}_{2}+5 \% \mathrm{CO}_{2}$ & $1.03 \mathrm{ac}$ & $0.95 \mathrm{bf}$ & $0.88 \mathrm{ei}$ & $0.84 \mathrm{gj}$ & $0.75 \mathrm{j} 1$ & $0.63 \mathrm{mn}$ & $0.84 \mathrm{~A}$ \\
\hline & $7 \% \mathrm{O}_{2}+5 \% \mathrm{CO}_{2}$ & $1.05 \mathrm{ab}$ & $0.93 \mathrm{cg}$ & $0.91 \mathrm{dh}$ & $0.81 \mathrm{hk}$ & $0.75 \mathrm{j} 1$ & $0.69 \ln$ & $0.85 \mathrm{~A}$ \\
\hline & SP (average) & $1.02 \mathrm{~A}$ & $0.91 \mathrm{~B}$ & $0.86 \mathrm{C}$ & $0.78 \mathrm{D}$ & $0.72 \mathrm{E}$ & $0.62 \mathrm{~F}$ & - \\
\hline
\end{tabular}

Values having the same alphabetical letter (s) did not significantly different according to LSD at 0.05 of probability. $\mathrm{AMA}=$ Active modified atmosphere, $\mathrm{SP}=$ Storage Period (day). 
comparing to control, by the tested AMA treatments in both seasons. Whereas, the highest FF $\left(0.89\right.$ and $\left.0.85 \mathrm{~kg} / \mathrm{cm}^{2}\right)$ were recorded by $7 \%$ $\mathrm{O}_{2}+5 \% \mathrm{CO}_{2}$ without significant differences with all other tested AMA treatments in the first and second seasons, respectively. While, the lowest FF values $\left(0.72\right.$ and $\left.0.78 \mathrm{~kg} / \mathrm{cm}^{2}\right)$ were recorded by the control (net) without significant differences with those treated by $3 \% \mathrm{O}_{2}+3 \%$ $\mathrm{CO}_{2}$ in both seasons and $5 \% \mathrm{O}_{2}+3 \% \mathrm{CO}_{2}$ in the second one.

Moreover, FF values during shelf life were significantly decreased as cold storage period was advanced. As such, the highest FF values were recorded at zero time (1.08 and $1.02 \mathrm{~kg}$ $\left./ \mathrm{cm}^{2}\right)$ in the first and second seasons, respectively. Whereas, the lowest values $(0.59$ and $0.62 \mathrm{~kg} / \mathrm{cm}^{2}$ ) were recorded at 35 days cold storage. The other periods, recorded in between values.

In addition, the interaction between the tested AMA treatments and shelf life after cold storage periods was significant in both seasons. As such, the highest FF values were recorded by all tested AMA treatments at zero time without significant differences between them, while, the lowest FF values were recorded by all tested AMA treatments at 35 days cold storage without significant differences among them in both tested seasons.

Generally, the results clarify that all tested AMA treatments maintained fruit firmness (FF) at high values as compared with the control, while, FF values was decreased with the advance in cold storage period. This was true either after cold storage or after shelf life periods.

These findings were in line with Themman et al. (1982) who reported that, Polygalacturanase (PG) and pectinastarase (PE) are the important enzymes involved in fruit softening by solubilizing the polygalacturonic acid in the pectin fraction of the cell walls during ripening. In this respect, PG activity increased while firmness decreased with progressive stage of maturation and its synthesis only occurs in response to ethylene (Grierson and Tucker, 1983). Moreover, High $\mathrm{CO}_{2}$ concentration inhibited ethylene production during tomato ripening (Herner, 1987). It was reported that elevated $\mathrm{CO}_{2}$ atmosphere slow down the softening rate, but the mechanism of controlled or modified atmosphere effects on texture of fresh fruits and vegetables is not fully understood (Kader, 1986). In addition, tomato fruits (cv'Liberto') harvested at the pink stage were stored at $13^{\circ} \mathrm{C}$ for 60 days in a plastic packaging system compared with unwrapped fruit as a control. All fruits softened progressively during storage, but those sealed in plastic film softened significantly more slowly than those stored unwrapped (Batu and Thompson, 1998). In tomato, with the onset of ripening, pectin degrading enzymes starts to accumulate and contribute to softening the cell walls (Shama and Alderson, 2005).

Firmness of tomato generally decreases with increasing in the duration of storage (Moneruzzaman et al., 2008). In fact, it has been proven that the modified atmosphere decreases the activity of the pectinesterase and polygaracturonase enzymes involved in the cell wall degradation (Akbudak et al., 2007 and 2012). Moreover, Vunnam et al. (2014) stated that tomato fruits stored under MA conditions maintained greater firmness than under non-MA conditions, as the mass loss was reduced more than ten-folds by MA storage compared to perforated non-MA storage. This is indicative that moisture content of the samples along with storage conditions plays a vital role in firmness. In this respect, Domínguez et al. (2016) studied effect of the packaging on fruit firmness of tomatoes cvs. Delizia and Pitenza stored at $13^{\circ} \mathrm{C}$ and then were stored for $48 \mathrm{hr}$., in air at $20^{\circ} \mathrm{C}$. They found that the modified atmosphere and the high humidity reached inside the packages slow down the process of ripening linked to the evolution of this quality parameter.

\section{Weight Losses Percentage (WL \%)}

\section{During cold storage periods}

Results in Table 2 show that the control (net) treatment recorded significantly highest WL (\%) $(1.29$ and 2.83\%) in the first and second seasons, respectively, as compared with all AMA treatments which showed significant reductions in WL (\%) without significant differences among them in most cases in both seasons. The lowest WL (\%) values (1.05 and $1.42 \%$ ) came from $3 \% \mathrm{O}_{2}+3 \% \mathrm{CO}_{2}$ treatment in the first and second seasons, respectively. 
Table 2. Effect of some active modified atmosphere (AMA) treatments on weight losses (WL \%) of tomato fruits $\mathrm{cv}$. Alisa during cold storage and shelf life periods during 2014 and 2015 seasons

\begin{tabular}{|c|c|c|c|c|c|c|c|c|}
\hline \multirow{3}{*}{\multicolumn{2}{|c|}{ AMA tr }} & \multicolumn{7}{|c|}{ Weight losses (\%) } \\
\hline & & \multicolumn{6}{|c|}{ Cold storage period (day) } & \multirow{2}{*}{$\underset{\text { (average) }}{\text { AMA }}$} \\
\hline & & $\mathbf{0}$ & 7 & 14 & 21 & 28 & 35 & \\
\hline & & \multicolumn{7}{|c|}{ First season (2014) } \\
\hline \multirow{6}{*}{$\sum$} & Control(Net) & $0.00 \mathrm{n}$ & $0.87 \mathrm{~m}$ & $0.87 \mathrm{~m}$ & $1.44 \mathrm{ei}$ & $1.92 b$ & $2.65 \mathrm{a}$ & $1.29 \mathrm{~A}$ \\
\hline & $3 \% \mathrm{O}_{2}+3 \% \mathrm{CO}_{2}$ & $0.00 \mathrm{n}$ & $0.85 \mathrm{~m}$ & $1.07 \mathrm{jm}$ & $1.04 \mathrm{jm}$ & $1.50 \mathrm{dh}$ & $1.88 \mathrm{bc}$ & $1.05 \mathrm{~B}$ \\
\hline & $5 \% \mathrm{O}_{2}+3 \% \mathrm{CO}_{2}$ & $0.00 \mathrm{n}$ & $0.85 \mathrm{~m}$ & $1.13 \mathrm{im}$ & $1.23 \mathrm{hl}$ & $1.29 \mathrm{gk}$ & $1.74 \mathrm{be}$ & $1.04 \mathrm{~B}$ \\
\hline & $5 \% \mathrm{O}_{2}+5 \% \mathrm{CO}_{2}$ & $0.00 n$ & $0.941 \mathrm{~m}$ & $1.00 \mathrm{~km}$ & $1.32 \mathrm{fj}$ & $1.53 \mathrm{dh}$ & $1.78 \mathrm{bd}$ & $1.09 \mathrm{~B}$ \\
\hline & $7 \% \mathrm{O}_{2}+5 \% \mathrm{CO}_{2}$ & $0.00 n$ & $0.84 \mathrm{~m}$ & $1.03 \mathrm{jm}$ & $1.51 \mathrm{dh}$ & $1.58 \mathrm{cg}$ & $1.63 \mathrm{bf}$ & $1.10 \mathrm{~B}$ \\
\hline & SP (average) & $0.00 \mathrm{~F}$ & $0.87 \mathrm{E}$ & $1.02 \mathrm{D}$ & $1.31 \mathrm{C}$ & $1.56 \mathrm{~B}$ & $1.93 \mathrm{~A}$ & - \\
\hline \multicolumn{9}{|c|}{ Second season (2015) } \\
\hline \multirow{8}{*}{$\sum_{2}^{\}$} & Control(Net) & $0.00 \mathrm{o}$ & $1.97 \mathrm{fl}$ & $2.64 \mathrm{cf}$ & $3.17 b c$ & $3.51 \mathrm{~b}$ & $5.67 \mathrm{a}$ & $2.83 \mathrm{~A}$ \\
\hline & $3 \% \mathrm{O}_{2}+3 \% \mathrm{CO}_{2}$ & $0.00 \mathrm{o}$ & $1.25 \mathrm{mn}$ & $1.28 \mathrm{mn}$ & $1.60 \mathrm{in}$ & $2.15 \mathrm{ek}$ & $2.25 \mathrm{ei}$ & $1.42 \mathrm{C}$ \\
\hline & $5 \% \mathrm{O}_{2}+3 \% \mathrm{CO}_{2}$ & $0.00 \mathrm{o}$ & $1.09 n$ & $1.70 \mathrm{hn}$ & $1.98 \mathrm{fl}$ & $2.33 \mathrm{dh}$ & $3.50 \mathrm{~b}$ & $1.77 \mathrm{~B}$ \\
\hline & $5 \% \mathrm{O}_{2}+5 \% \mathrm{CO}_{2}$ & $0.00 \mathrm{o}$ & $1.35 \ln$ & $1.80 \mathrm{gm}$ & $2.20 \mathrm{ej}$ & $2.22 \mathrm{ej}$ & $2.95 \mathrm{bd}$ & $1.75 \mathrm{~B}$ \\
\hline & $7 \% \mathrm{O}_{2}+5 \% \mathrm{CO}_{2}$ & $0.00 \mathrm{o}$ & $1.24 \mathrm{mn}$ & $1.51 \mathrm{kn}$ & $1.54 \mathrm{jn}$ & $2.44 \mathrm{dg}$ & 2.71ce & $1.57 \mathrm{BC}$ \\
\hline & SP (average) & $0.00 \mathrm{E}$ & $1.38 \mathrm{D}$ & $1.78 \mathrm{C}$ & $2.10 \mathrm{C}$ & $2.53 \mathrm{~B}$ & $3.41 \mathrm{~A}$ & - \\
\hline & & \multicolumn{7}{|c|}{5 days shelf life } \\
\hline & & & & Fir & t season & 2014) & & \\
\hline \multirow{6}{*}{$\sum_{2}^{\}$} & Control(Net) & $3.83 \mathrm{o}$ & $5.13 \mathrm{~km}$ & $6.99 \mathrm{eg}$ & $7.40 \mathrm{df}$ & $7.84 \mathrm{bd}$ & $9.01 \mathrm{a}$ & $6.70 \mathrm{~A}$ \\
\hline & $3 \% \mathrm{O}_{2}+3 \% \mathrm{CO}_{2}$ & $3.89 \mathrm{o}$ & $4.791 \mathrm{ln}$ & $5.53 \mathrm{jk}$ & $6.58 \mathrm{gi}$ & $7.36 \mathrm{df}$ & $7.97 \mathrm{bd}$ & $6.02 \mathrm{~B}$ \\
\hline & $5 \% \mathrm{O}_{2}+3 \% \mathrm{CO}_{2}$ & $4.16 \mathrm{no}$ & $5.06 \mathrm{~km}$ & $5.53 \mathrm{j} 1$ & $6.96 \mathrm{eg}$ & $7.43 \mathrm{df}$ & $7.51 \mathrm{cf}$ & $6.11 \mathrm{~B}$ \\
\hline & $5 \% \mathrm{O}_{2}+5 \% \mathrm{CO}_{2}$ & $4.31 \mathrm{mo}$ & $5.21 \mathrm{j} 1$ & $5.96 \mathrm{ij}$ & $6.74 \mathrm{fh}$ & $6.84 \mathrm{eg}$ & $8.36 \mathrm{ab}$ & $6.23 \mathrm{AB}$ \\
\hline & $7 \% \mathrm{O}_{2}+5 \% \mathrm{CO}_{2}$ & 4.09 no & $4.99 \mathrm{~km}$ & $6.00 \mathrm{hj}$ & $6.38 \mathrm{gi}$ & $7.65 \mathrm{be}$ & $8.31 \mathrm{ac}$ & $6.23 \mathrm{AB}$ \\
\hline & SP (average) & $4.05 \mathrm{~F}$ & $5.03 \mathrm{E}$ & $6.00 \mathrm{D}$ & $6.81 \mathrm{C}$ & $7.42 \mathrm{~B}$ & $8.23 \mathrm{~A}$ & \\
\hline \multicolumn{9}{|c|}{ Second season (2015) } \\
\hline \multirow{6}{*}{$\sum$} & Control(Net) & $4.61 \mathrm{ko}$ & $5.91 \mathrm{gk}$ & $7.92 \mathrm{ce}$ & $8.93 \mathrm{bd}$ & $9.86 \mathrm{ab}$ & $11.57 \mathrm{a}$ & $8.13 \mathrm{~A}$ \\
\hline & $3 \% \mathrm{O}_{2}+3 \% \mathrm{CO}_{2}$ & $3.52 \mathrm{no}$ & $4.75 \mathrm{kn}$ & $5.37 \mathrm{im}$ & $6.80 \mathrm{ei}$ & $7.41 \mathrm{dh}$ & $8.03 \mathrm{ce}$ & $5.98 \mathrm{~B}$ \\
\hline & $5 \% \mathrm{O}_{2}+3 \% \mathrm{CO}_{2}$ & $2.90 \mathrm{o}$ & $3.77 \mathrm{mo}$ & $6.51 \mathrm{ej}$ & $7.23 \mathrm{dh}$ & $7.66 \mathrm{cg}$ & $9.19 \mathrm{bc}$ & $6.21 \mathrm{~B}$ \\
\hline & $5 \% \mathrm{O}_{2}+5 \% \mathrm{CO}_{2}$ & 2.880 & 4.1110 & $6.03 \mathrm{fk}$ & $6.94 \mathrm{ei}$ & $7.19 \mathrm{dh}$ & $9.24 b c$ & $6.06 \mathrm{~B}$ \\
\hline & $7 \% \mathrm{O}_{2}+5 \% \mathrm{CO}_{2}$ & $4.55 \mathrm{ko}$ & $4.86 \mathrm{jn}$ & $5.71 \mathrm{hl}$ & $5.78 \mathrm{hl}$ & $6.00 \mathrm{fk}$ & $7.76 \mathrm{cf}$ & $5.77 \mathrm{~B}$ \\
\hline & SP (average) & $3.69 \mathrm{E}$ & $4.68 \mathrm{D}$ & $6.30 \mathrm{C}$ & $7.13 \mathrm{~B}$ & $7.62 \mathrm{~B}$ & $9.15 \mathrm{~A}$ & - \\
\hline
\end{tabular}

Values having the same alphabetical letter(s) did not significantly different according to LSD at 0.05 of probability. AMA $=$ Active modified atmosphere, $\mathrm{SP}=$ Storage period (day). 
The results also show that, fruit WL (\%) was markedly increased as cold storage period increased. The highest values (1.93 and $3.41 \%$ in the first and second seasons, respectively) resulted at 35 days cold storage.

The interaction between AMA treatments and cold storage period was significant in both seasons. The all AMA treatments $\times 7$ and 14 days cold storage recorded the least WL (\%) values in the two seasons. Whereas the control treatment $\times 35$ days of cold storage was recorded the highest WL (\%) (2.65 and 5.67\% in the first and second seasons, respectively).

\section{During shelf life periods}

The tested treatments significantly affected WL (\%) after 5 days of shelf life in both seasons. The highest WL (\%) was recorded by the control $(6.70$ and $8.13 \%$ in the first and second seasons, respectively). While, the lowest WL(\%) was recorded by all other AMA treatment without significant differences among them in both seasons.

The results also indicate that WL (\%) was progressively increased during shelf life period and /or cold storage period to reach a maximum values $(8.23$ and $9.15 \%$ in the first and second seasons, respectively) at 35 days cold storage. While, the minimum values (4.05 and 3.69\% in the first and second seasons, respectively) were recorded at zero time and 5 days shelf life.

Generally, the present work revealed that fruits WL (\%) were increased as cold storage period increased and the control treatment raised WL (\%) compared with AMA treatments during cold storage and after shelf life periods.

The reduction in WL (\%) with AMA treatments was in agreement with Gharezi et al. (2012) working on Cherry tomato stored at $10^{\circ} \mathrm{C}$ \pm 2 up to 14 days of storage. The WL progressively increased with increasing storage period, irrespective of the storage condition and the previous treatments. This could be attributed to the maintenance of high humidity in the micro atmosphere within the packages by the respiring fruits and due to low water vapor transmission rates of packaging material (Moneruzzaman et al., 2009). Cold stored fruits had a low weight loss due to temperature effects on vapor pressure difference and increased water retention (Tasdelen and Bayindirli, 1998).
In addition, Batu and Thompson (1998) reported that weight loss of the plastic film packed tomato fruits were lower and linearly increased throughout storage period. While, unwrapped fruits has achieved the highest weight losses. The lowest weight loss of fruit sealed in different films may be due to the lower respiration rate of the tomatoes which would have occurred with the higher $\mathrm{CO}_{2}$ and lower $\mathrm{O}_{2}$ levels inside these films. Moreover, the weight loss reduction is mainly a consequence of the water vapor accumulation within the plastic bags during storage (Akbudak et al., 2012).

Water loss can be one of the main causes of deterioration, since it not only results in indirect quantities losses, but also causes losses in appearance (due to wilting and shriveling) and nutritional quality. MA does not directly affect the rate of water loss, but the need for a gas tight environment for MA storage and transport often results in significantly higher relative humidity around the commodity and consequently reduces water loss compared to air storage (Kader, 1986). The present study demonstrates that the high humidity obtained within the MA packages significantly delayed fruit water loss, leading to inhibition of ripening (expressed as peel color changes).

\section{Fruit Decay Percentage (\%)}

\section{During cold storage periods}

Results in Table 3 also reveal that the tested AMA treatments failed to show any significant differences regarding fruits decay percentage in both tested seasons. However, fruit decay percentage was significantly increased with the advance in cold storage period in both tested seasons. As such, the highest fruit decay percentage (2.66 and $4.66 \%$ ) was recorded at 35 days in the first and second seasons, respectively. While, all other periods came in the second rank without any decayed fruit in both seasons.

The interaction between AMA treatments and cold storage period was significant in both seasons. All tested treatments did not appear any decayed fruits until 28 days of cold storage. While, at 35 days of cold storage did not happen any decayed fruits in treatment $7 \% \mathrm{O}_{2}+5 \% \mathrm{CO}_{2}$ in both seasons without significant differences with treatment $5 \% \mathrm{O}_{2}+5 \% \mathrm{CO}_{2}$ in the second 
Table 3. Effect of some active modified atmosphere (AMA) treatments on fruit decay percentage (\%) of tomato fruits during cold storage and shelf life periods during 2014 and 2015 seasons

\begin{tabular}{|c|c|c|c|c|c|c|c|c|}
\hline & & \multicolumn{7}{|c|}{ Fruit decay percentage (\%) } \\
\hline & & \multicolumn{6}{|c|}{ Cold storage period (day) } & \multirow{2}{*}{$\begin{array}{c}\text { AMA } \\
\text { (average) }\end{array}$} \\
\hline \multicolumn{2}{|c|}{ AMA treatment } & $\mathbf{0}$ & 7 & 14 & 21 & 28 & 35 & \\
\hline \multirow{7}{*}{$\sum$} & \multirow[b]{2}{*}{ Control (Net) } & \multicolumn{7}{|c|}{ First season (2014) } \\
\hline & & $0.00 \mathrm{~b}$ & $0.00 \mathrm{~b}$ & $0.00 \mathrm{~b}$ & $0.00 \mathrm{~b}$ & $0.00 \mathrm{~b}$ & $3.33 \mathrm{a}$ & $0.55 \mathrm{~A}$ \\
\hline & $3 \% \mathrm{O}_{2}+3 \% \mathrm{CO}_{2}$ & $0.00 \mathrm{~b}$ & $0.00 \mathrm{~b}$ & $0.00 \mathrm{~b}$ & $0.00 \mathrm{~b}$ & $0.00 \mathrm{~b}$ & $3.33 \mathrm{a}$ & $0.55 \mathrm{~A}$ \\
\hline & $5 \% \mathrm{O}_{2}+3 \% \mathrm{CO}_{2}$ & $0.00 \mathrm{~b}$ & $0.00 \mathrm{~b}$ & $0.00 \mathrm{~b}$ & $0.00 \mathrm{~b}$ & $0.00 \mathrm{~b}$ & $3.33 \mathrm{a}$ & $0.55 \mathrm{~A}$ \\
\hline & $5 \% \mathrm{O}_{2}+5 \% \mathrm{CO}_{2}$ & $0.00 \mathrm{~b}$ & $0.00 \mathrm{~b}$ & $0.00 \mathrm{~b}$ & $0.00 \mathrm{~b}$ & $0.00 \mathrm{~b}$ & $3.33 \mathrm{a}$ & $0.55 \mathrm{~A}$ \\
\hline & $7 \% \mathrm{O}_{2}+5 \% \mathrm{CO}_{2}$ & $0.00 \mathrm{~b}$ & $0.00 \mathrm{~b}$ & $0.00 \mathrm{~b}$ & $0.00 \mathrm{~b}$ & $0.00 \mathrm{~b}$ & $0.00 \mathrm{~b}$ & $0.00 \mathrm{~A}$ \\
\hline & SP (average) & $0.00 \mathrm{~B}$ & $0.00 \mathrm{~B}$ & $0.00 \mathrm{~B}$ & $0.00 \mathrm{~B}$ & $0.00 \mathrm{~B}$ & $2.66 \mathrm{~A}$ & - \\
\hline & & & & & ond sea: & $\mathrm{n}(\mathbf{2 0 1 5})$ & & \\
\hline & Control (Net) & $0.00 \mathrm{~b}$ & $0.00 \mathrm{~b}$ & $0.00 \mathrm{~b}$ & $0.00 \mathrm{~b}$ & $0.00 \mathrm{~b}$ & $6.66 \mathrm{a}$ & $1.11 \mathrm{~A}$ \\
\hline & $3 \% \mathrm{O}_{2}+3 \% \mathrm{CO}_{2}$ & $0.00 \mathrm{~b}$ & $0.00 \mathrm{~b}$ & $0.00 \mathrm{~b}$ & $0.00 \mathrm{~b}$ & $0.00 \mathrm{~b}$ & $6.66 \mathrm{a}$ & $1.11 \mathrm{~A}$ \\
\hline 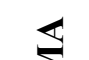 & $5 \% \mathrm{O}_{2}+3 \% \mathrm{CO}_{2}$ & $0.00 \mathrm{~b}$ & $0.00 \mathrm{~b}$ & $0.00 \mathrm{~b}$ & $0.00 \mathrm{~b}$ & $0.00 \mathrm{~b}$ & $6.66 \mathrm{a}$ & $1.11 \mathrm{~A}$ \\
\hline 之 & $5 \% \mathrm{O}_{2}+5 \% \mathrm{CO}_{2}$ & $0.00 \mathrm{~b}$ & $0.00 \mathrm{~b}$ & $0.00 \mathrm{~b}$ & $0.00 \mathrm{~b}$ & $0.00 \mathrm{~b}$ & $3.33 \mathrm{ab}$ & $0.55 \mathrm{~A}$ \\
\hline & $7 \% \mathrm{O}_{2}+5 \% \mathrm{CO}_{2}$ & $0.00 \mathrm{~b}$ & $0.00 \mathrm{~b}$ & $0.00 \mathrm{~b}$ & $0.00 \mathrm{~b}$ & $0.00 \mathrm{~b}$ & $0.00 \mathrm{~b}$ & $0.00 \mathrm{~A}$ \\
\hline & SP (average) & $0.00 \mathrm{~B}$ & $0.00 \mathrm{~B}$ & $0.00 \mathrm{~B}$ & $0.00 \mathrm{~B}$ & $0.00 \mathrm{~B}$ & $4.66 \mathrm{~A}$ & - \\
\hline & & & & & days $s$ & If life & & \\
\hline & & & & & st seasc & (2014) & & \\
\hline & Control (Net) & $0.00 \mathrm{~b}$ & $0.00 \mathrm{~b}$ & $0.00 \mathrm{~b}$ & $0.00 \mathrm{~b}$ & $0.00 \mathrm{~b}$ & $6.66 \mathrm{a}$ & $1.11 \mathrm{~A}$ \\
\hline & $3 \% \mathrm{O}_{2}+3 \% \mathrm{CO}_{2}$ & $0.00 \mathrm{~b}$ & $0.00 \mathrm{~b}$ & $0.00 \mathrm{~b}$ & $0.00 \mathrm{~b}$ & $0.00 \mathrm{~b}$ & $3.33 \mathrm{ab}$ & $0.55 \mathrm{~A}$ \\
\hline$\S$ & $5 \% \mathrm{O}_{2}+3 \% \mathrm{CO}_{2}$ & $0.00 \mathrm{~b}$ & $0.00 \mathrm{~b}$ & $0.00 \mathrm{~b}$ & $0.00 \mathrm{~b}$ & $0.00 \mathrm{~b}$ & $3.33 \mathrm{ab}$ & $0.55 \mathrm{~A}$ \\
\hline$\sum$ & $5 \% \mathrm{O}_{2}+5 \% \mathrm{CO}_{2}$ & $0.00 \mathrm{~b}$ & $0.00 \mathrm{~b}$ & $0.00 \mathrm{~b}$ & $0.00 \mathrm{~b}$ & $0.00 \mathrm{~b}$ & $6.66 \mathrm{a}$ & $1.11 \mathrm{~A}$ \\
\hline & $7 \% \mathrm{O}_{2}+5 \% \mathrm{CO}_{2}$ & $0.00 \mathrm{~b}$ & $0.00 \mathrm{~b}$ & $0.00 \mathrm{~b}$ & $0.00 \mathrm{~b}$ & $0.00 \mathrm{~b}$ & $0.00 \mathrm{~b}$ & $0.00 \mathrm{~A}$ \\
\hline & SP (average) & $0.00 \mathrm{~B}$ & $0.00 \mathrm{~B}$ & $0.00 \mathrm{~B}$ & $0.00 \mathrm{~B}$ & $0.00 \mathrm{~B}$ & $4.00 \mathrm{~A}$ & - \\
\hline & & & & & ond seas & $n(2015)$ & & \\
\hline & Control (Net) & $0.00 \mathrm{a}$ & $0.00 \mathrm{a}$ & $0.00 \mathrm{a}$ & $0.00 \mathrm{a}$ & $3.33 \mathrm{a}$ & $6.66 \mathrm{a}$ & $1.66 \mathrm{~A}$ \\
\hline & $3 \% \mathrm{O}_{2}+3 \% \mathrm{CO}_{2}$ & $0.00 \mathrm{a}$ & $0.00 \mathrm{a}$ & $0.00 \mathrm{a}$ & $0.00 \mathrm{a}$ & $0.00 \mathrm{a}$ & $6.66 \mathrm{a}$ & $1.11 \mathrm{~A}$ \\
\hline & $5 \% \mathrm{O}_{2}+3 \% \mathrm{CO}_{2}$ & $0.00 \mathrm{a}$ & $0.00 \mathrm{a}$ & $0.00 \mathrm{a}$ & $0.00 \mathrm{a}$ & $3.33 \mathrm{a}$ & $6.66 \mathrm{a}$ & $1.66 \mathrm{~A}$ \\
\hline$\sum$ & $5 \% \mathrm{O}_{2}+5 \% \mathrm{CO}_{2}$ & $0.00 \mathrm{a}$ & $0.00 \mathrm{a}$ & $0.00 \mathrm{a}$ & $0.00 \mathrm{a}$ & $0.00 \mathrm{a}$ & $6.66 \mathrm{a}$ & $1.11 \mathrm{~A}$ \\
\hline & $7 \% \mathrm{O}_{2}+5 \% \mathrm{CO}_{2}$ & $0.00 \mathrm{a}$ & $0.00 \mathrm{a}$ & $0.00 \mathrm{a}$ & $0.00 \mathrm{a}$ & $0.00 \mathrm{a}$ & $3.33 \mathrm{a}$ & $0.55 \mathrm{~A}$ \\
\hline & SP (average) & $0.00 \mathrm{~B}$ & $0.00 \mathrm{~B}$ & $0.00 \mathrm{~B}$ & $0.00 \mathrm{~B}$ & $1.33 \mathrm{~B}$ & $6.00 \mathrm{~A}$ & - \\
\hline
\end{tabular}

Values having the same alphabetical letter(s) did not significantly different according to LSD at 0.05 of probability $\mathrm{AMA}=$ Active modified atmosphere, $\mathrm{SP}=$ Storage period (day). 
season only. The other treatments recorded $3.33 \%$ in the first season and $6.66 \%$ in the second one without significant differences between them.

\section{During shelf life periods}

Results in Table 3 also reveal that the tested AMA treatments failed to show any significant differences regarding fruits decay percentage during shelf life period in both tested seasons. However, fruit decay percentage was significantly increased with the advance in cold storage period in both tested seasons. Where the decayed fruit started to appear at 35 days in the first season and at 28 days in the second one. The highest fruit decay percentage (4.00 and $6.00 \%$ ) was recorded at 35 days, while, all other periods came in the second rank without significant differences among them in both seasons.

The interaction between AMA treatments and cold storage period was significant in the first season only. As such, all tested treatments except those $7 \% \mathrm{O}_{2}+5 \% \mathrm{CO}_{2} \times 35$ days recorded the highest decay percentage without significant differences between them. While, all other treatments $\times$ all other periods came in the second rank without any decayed fruits.

Generally, the results clear that tomato fruits did not suffer from any decay along the whole cold storage period with all tested AMA treatments, except for a few decayed fruits which, started to appear at 35 days in the first season and at 28 days in the second one. The lower fruit decay in the present study might be due to a better fruits disinfection before the onset of the cold storage.

The reduction in fruit decay percentage with MA was in agreement with Batu and Thompson (1998) working on tomato fruits (cv'Liberto') harvested at the pink stage and stored at $13^{\circ} \mathrm{C}$ for 60 days in a plastic packaging system. Decay was first observed on one fruit out of 60 after 40 days storage. All treatments showed some rotting after 50 days storage which increased again after 60 days. $8 \%$ of fruit had some infection after 50 days rising to $16 \%$ after 60 days. Moreover, Buescher (1979) showed that $66 \%$ of the tomatoes were decayed after 6 weeks at $12^{\circ} \mathrm{C}$ in air. An average of only $3.5 \%$ was decayed during the same period in atmospheres of $3 \%$ oxygen with 0,3 or $5 \% \mathrm{CO}_{2}$ environments.

\section{Ascorbic Acid (vitamin C) Content (mg/100ml Juice)}

\section{During cold storage periods}

Results in Table 4 clarify that the tested AMA treatments had significant effect on ascorbic acid content in tomato fruit juice in both tested seasons. As such, the uppermost values of ascorbic acid (16.64 and $15.84 \mathrm{mg} / 100$ $\mathrm{ml}$ juice in the first and second seasons, respectively), were detected in $7 \% \mathrm{O}_{2}+5 \% \mathrm{CO}_{2}$ without significant differences with those treated by $5 \% \mathrm{O}_{2}+5 \% \mathrm{CO}_{2}$ and $5 \% \mathrm{O}_{2}+3 \% \mathrm{CO}_{2}$ in both tested seasons. In addition, the lowest values were observed with net (14.25 and 14.75 $\mathrm{mg} / 100 \mathrm{ml}$ juice in the first and second seasons, respectively). Fruits treated by $3 \% \mathrm{O}_{2}+3 \% \mathrm{CO}_{2}$ recorded intermediate values of ascorbic acid content without significant differences with those treated by $5 \% \mathrm{O}_{2}+3 \% \mathrm{CO}_{2}$ in both tested seasons.

Moreover, ascorbic acid content showed continuous and sharp reduction with the advance in cold storage periods in both seasons. As such, the highest values of ascorbic acid content were recorded at zero time (19.37 and $19.68 \mathrm{mg} / 100$ $\mathrm{ml}$ juice) and significantly decreased with increasing in storage duration to reach the least values (11.76 and $11.59 \mathrm{mg} / 100 \mathrm{ml}$ juice) at 35 days cold storage in the first and second seasons, respectively. Fruits of the other sampling periods recorded intermediate values of ascorbic acid content.

The interaction between AMA treatments and cold storage period was significant in both seasons. The highest values of ascorbic acid content were recorded by all tested treatments at zero time, without significant differences among them in both seasons. Whereas, the least values were recorded by the control (net) treatment, at 35 days cold storage without significant differences with those treated by $3 \% \mathrm{O}_{2}+3 \%$ $\mathrm{CO}_{2}$ in the second season only.

\section{During shelf life periods}

Results in Table 4 clarify that the tested AMA treatments had significant effect on ascorbic acid content in tomato fruit juice during shelf life in both tested seasons. As such, the 
Table 4. Effect of some active modified atmosphere (AMA) treatments on ascorbic acid content $(\mathrm{mg} / 100 \mathrm{ml}$ juice) of tomato fruits $\mathrm{cv}$. Alisa during cold storage and shelf life periods during 2014 and 2015 seasons

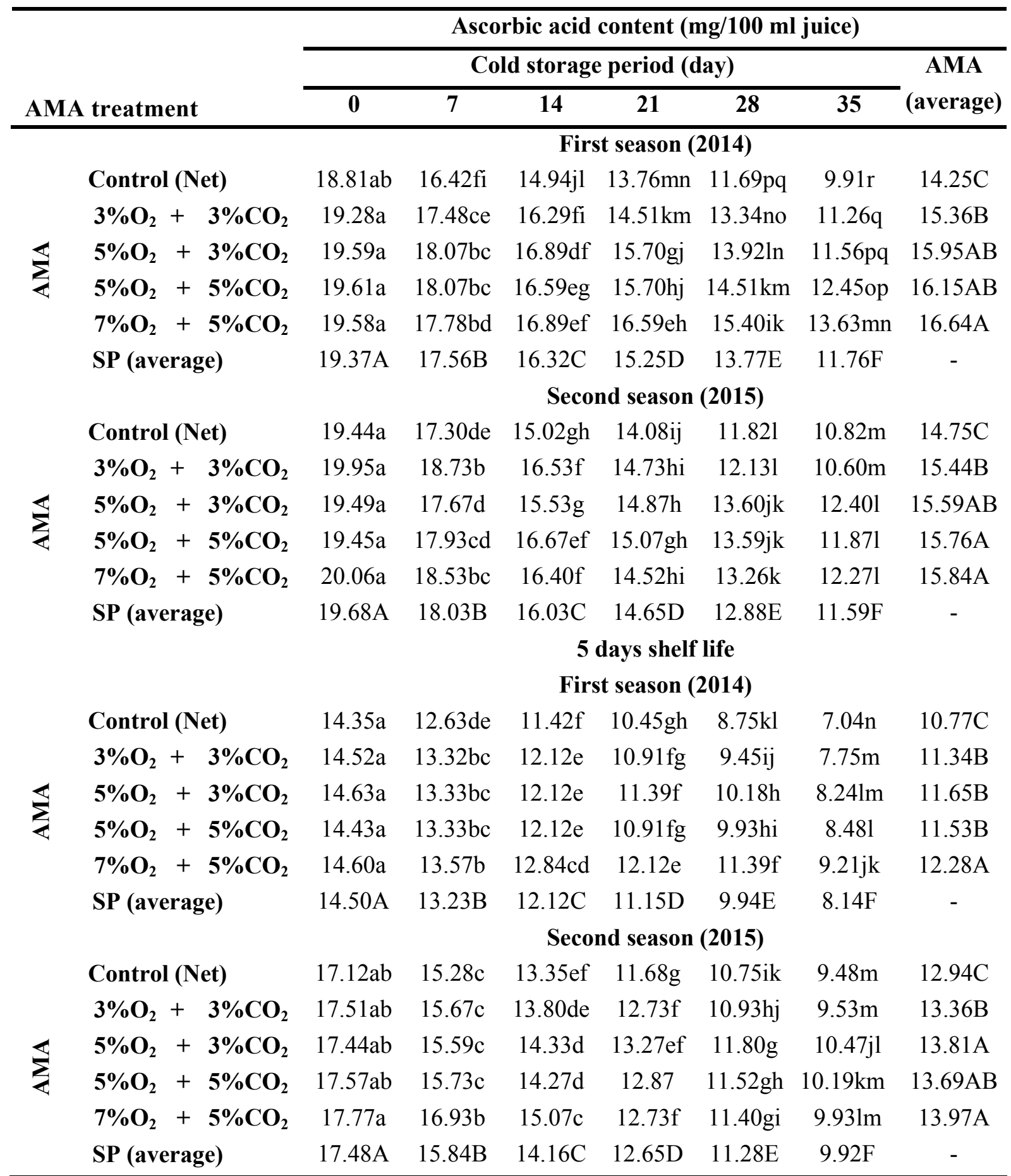

Values having the same alphabetical letter(s) did not significantly different according to LSD at 0.05 of probability. $\mathrm{AMA}=$ modified atmosphere, $\mathrm{SP}=$ Storage period (day). 
highest values of ascorbic acid (12.28 and 13.97 $\mathrm{mg} / 100 \mathrm{ml}$ juice in the first and second seasons, respectively), were detected in $7 \% \mathrm{O}_{2}+5 \% \mathrm{CO}_{2}$ without significant differences with those treated by $5 \% \mathrm{O}_{2}+5 \% \mathrm{CO}_{2}$ and $5 \% \mathrm{O}_{2}+3 \% \mathrm{CO}_{2}$ in the second season only. In addition, the lowest values were observed with control (10.77 and $12.94 \mathrm{mg} / 100 \mathrm{ml}$ juice in the first and second seasons, respectively). Fruits treated by $3 \% \mathrm{O}_{2}+$ $3 \% \quad \mathrm{CO}_{2}$ recorded intermediate values of ascorbic acid content without significant differences with those treated by $5 \% \mathrm{O}_{2}+3 \%$ $\mathrm{CO}_{2}$ and $5 \% \mathrm{O}_{2}+5 \% \mathrm{CO}_{2}$ in the first season and those treated by $5 \% \mathrm{O}_{2}+5 \% \mathrm{CO}_{2}$ in the second one.

The interaction between AMA treatments and cold storage period was significant during shelf life in both seasons. The highest values of ascorbic acid content were recorded by all tested treatments at zero time, without significant differences among them in both seasons. Whereas, the least values were recorded by the control (net) treatment, at 35 days cold storage $(7.04$ and $9.48 \mathrm{mg} / 100 \mathrm{ml}$ juice in the first and second seasons, respectively) without significant differences with those treated by $3 \%$ $\mathrm{O}_{2}+3 \% \mathrm{CO}_{2}, 5 \% \mathrm{O}_{2}+5 \% \mathrm{CO}_{2}$ and $7 \% \mathrm{O}_{2}+5 \%$ $\mathrm{CO}_{2}$ in the second season only.

Generally, ascorbic acid content retained significantly higher values with AMA treatments, while, was decreased with the advance of cold storage period.

These findings were in line with Lee and Kader (2000) who reported that losses of vitamin C, (ascorbic acid) are accelerated at higher temperatures and with longer storage durations. However, some chilling sensitive crops show more losses in vitamin $\mathrm{C}$ at lower temperatures. The loss of vitamin $\mathrm{C}$ after harvest can be reduced by storing fruits and vegetables in reduced $\mathrm{O}_{2}$ and/or up to $10 \% \quad \mathrm{CO}_{2}$ atmospheres; higher $\mathrm{CO}_{2}$ levels can accelerate vitamin $\mathrm{C}$ loss. Tomatoes are rich source of ascorbic acid. The ascorbic acid content of ripe tomato ranged from $15 \mathrm{mg}$ to $23 \mathrm{mg} / 100 \mathrm{~g}$ fruit (Sánchez-Moreno et al., 2006). Preservation of ascorbic acid content during storage is a difficult task since it undergoes oxidation (Cantwell et al., 2009). Moreover, Gharezi et al. (2012) stored Cherry tomato cv. Marilee red harvested at pink stages at ambient temperature $\left(25^{\circ} \mathrm{C} \pm 2\right)$ as control or cold storage conditions $\left(10^{\circ} \mathrm{C} \pm 2\right)$ up to 14 days. They found that, ascorbic acid contents significantly decreased during storage. Among all treatments, control showed lowest ascorbic acid contents. Loss of ascorbic acid in cold stored tomatoes was significantly slower than air stored tomatoes.

\section{Lycopene Content mg/kg}

\section{During cold storage periods}

Results in Table 5 clarify that control treatment (net) achieved significantly highest juice lycopene content $(87.41$ and $74.25 \mathrm{mg} / \mathrm{kg}$ in the first and second seasons, respectively). Whereas, $7 \% \mathrm{O}_{2}+5 \% \mathrm{CO}_{2}$ treatment recorded the lowest juice lycopene content (74.18 and $68.33 \mathrm{mg} / \mathrm{kg}$ in the first and second seasons, respectively) without significant differences with those treated by $5 \% \mathrm{O}_{2}+5 \% \mathrm{CO}_{2}$ in the second season only. The other tested treatment recorded intermediate values.

Moreover, the results also indicate that juice lycopene content was progressively increased with the advance in cold storage period. As such, the lowest values $(64.98$ and $55.39 \mathrm{mg} / \mathrm{kg}$ were recorded at zero time in the first and second seasons, respectively).While, the highest values $(98.35$ and $85.88 \mathrm{mg} / \mathrm{kg}$ in the first and second seasons, respectively) were recorded at 35 days. Values of lycopene content during the other storing periods came in between.

In addition, the interaction between AMA treatments and cold storage period was found to be significant in both seasons. Whereas, the highest lycopene content (103.78 and $91.91 \mathrm{mg} / \mathrm{kg}$ were recorded by control (net) $\times 35$ days, while all tested treatments at zero time recorded the lowest values without significant differences between them. The other combinations recorded intermediate values.

\section{During shelf life periods}

Results in Table 5 also show that the control treatment (net) recorded significantly highest juice lycopene content $(95.50$ and $79.37 \mathrm{mg} / \mathrm{kg}$ in the first and second seasons, respectively). Whereas, fruits treated by $7 \% \mathrm{O}_{2}+5 \% \mathrm{CO}_{2}$ 
Table 5. Effect of some active modified atmosphere (AMA) treatments on lycopene content $(\mathrm{mg} / \mathrm{kg})$ of tomato fruits cv. Alisa during cold storage and shelf life periods during 2014 and 2015 seasons

\begin{tabular}{|c|c|c|c|c|c|c|c|c|}
\hline \multirow{3}{*}{\multicolumn{2}{|c|}{ AMA treatment }} & \multicolumn{7}{|c|}{ Lycopene content (mg/kg) } \\
\hline & & \multicolumn{6}{|c|}{ Cold storage period (day) } & \multirow{2}{*}{$\begin{array}{c}\text { AMA } \\
\text { (average) }\end{array}$} \\
\hline & & $\mathbf{0}$ & 7 & 14 & 21 & 28 & 35 & \\
\hline & & \multicolumn{7}{|c|}{ First season (2014) } \\
\hline \multirow{6}{*}{$\sum$} & Control (Net) & $65.89 \mathrm{~m}$ & $75.44 \mathrm{jk}$ & $86.45 \mathrm{~g}$ & $93.80 \mathrm{e}$ & $99.10 b c$ & $103.78 \mathrm{a}$ & $87.41 \mathrm{~A}$ \\
\hline & $3 \% \mathrm{O}_{2}+3 \% \mathrm{CO}_{2}$ & $65.90 \mathrm{~m}$ & $74.96 \mathrm{k}$ & $86.77 \mathrm{~g}$ & $93.91 \mathrm{e}$ & $96.77 \mathrm{~cd}$ & $100.91 b$ & $86.53 \mathrm{~B}$ \\
\hline & $5 \% \mathrm{O}_{2}+3 \% \mathrm{CO}_{2}$ & $63.93 \mathrm{~m}$ & $77.40 \mathrm{ij}$ & $85.25 \mathrm{~g}$ & $90.92 f$ & $95.25 \mathrm{de}$ & $100.92 b$ & $85.51 \mathrm{C}$ \\
\hline & $5 \% \mathrm{O}_{2}+5 \% \mathrm{CO}_{2}$ & $64.78 \mathrm{~m}$ & 69.901 & $74.51 \mathrm{k}$ & $81.82 \mathrm{~h}$ & $89.60 \mathrm{f}$ & $96.60 \mathrm{~d}$ & $79.53 \mathrm{D}$ \\
\hline & $7 \% \mathrm{O}_{2}+5 \% \mathrm{CO}_{2}$ & $64.42 \mathrm{~m}$ & $65.58 \mathrm{~m}$ & 69.971 & $75.96 \mathrm{jk}$ & 79.60hi & $89.56 f$ & $74.18 \mathrm{E}$ \\
\hline & SP (average) & $64.98 \mathrm{~F}$ & $72.65 \mathrm{E}$ & 80.59D & $87.28 \mathrm{C}$ & $92.06 \mathrm{~B}$ & $98.35 \mathrm{~A}$ & - \\
\hline \multicolumn{9}{|c|}{ Second season (2015) } \\
\hline \multirow{6}{*}{$\sum$} & Control (Net) & $54.65 n$ & $65.11 \mathrm{k}$ & $70.71 \mathrm{hi}$ & $78.36 \mathrm{e}$ & $84.79 \mathrm{c}$ & $91.91 \mathrm{a}$ & $74.25 \mathrm{~A}$ \\
\hline & $3 \% \mathrm{O}_{2}+3 \% \mathrm{CO}_{2}$ & $55.66 \mathrm{mn}$ & 62.491 & $68.70 \mathrm{j}$ & $73.27 \mathrm{~g}$ & $78.92 \mathrm{e}$ & $87.14 \mathrm{~b}$ & $71.03 \mathrm{~B}$ \\
\hline & $5 \% \mathrm{O}_{2}+3 \% \mathrm{CO}_{2}$ & $55.83 \mathrm{mn}$ & 62.661 & $65.85 \mathrm{k}$ & $72.24 \mathrm{gh}$ & $78.43 \mathrm{e}$ & $83.76 \mathrm{~cd}$ & $69.79 \mathrm{C}$ \\
\hline & $5 \% \mathrm{O}_{2}+5 \% \mathrm{CO}_{2}$ & $56.31 \mathrm{mn}$ & 61.141 & $64.99 \mathrm{k}$ & $69.80 \mathrm{ij}$ & $75.79 f$ & $82.49 \mathrm{~d}$ & $68.42 \mathrm{D}$ \\
\hline & $7 \% \mathrm{O}_{2}+5 \% \mathrm{CO}_{2}$ & $54.52 \mathrm{n}$ & $57.35 \mathrm{~m}$ & $64.67 \mathrm{k}$ & 71.05hi & $78.25 \mathrm{e}$ & $84.14 \mathrm{~cd}$ & 68.33D \\
\hline & SP (average) & $39 \mathrm{~F}$ & $61.75 \mathrm{E}$ & $66.98 \mathrm{D}$ & $72.94 \mathrm{C}$ & 79.23B & $85.88 \mathrm{~A}$ & - \\
\hline \multirow{8}{*}{$\sum$} & & \multicolumn{7}{|c|}{5 days shelf life } \\
\hline & & \multicolumn{7}{|c|}{ First season (2014) } \\
\hline & Control (Net) & $73.48 n$ & 84.491 & $93.85 \mathrm{j}$ & $101.78 \mathrm{ef}$ & $107.56 b c$ & $111.89 \mathrm{a}$ & $95.50 \mathrm{~A}$ \\
\hline & $3 \% \mathrm{O}_{2}+3 \% \mathrm{CO}_{2}$ & $71.69 n$ & $79.24 \mathrm{~m}$ & 85.241 & $96.44 \mathrm{i}$ & $100.63 \mathrm{fg}$ & $105.53 \mathrm{~cd}$ & 89.79B \\
\hline & $5 \% \mathrm{O}_{2}+3 \% \mathrm{CO}_{2}$ & $72.96 n$ & $80.01 \mathrm{~m}$ & 86.381 & $93.82 \mathrm{j}$ & $98.78 \mathrm{gi}$ & $104.92 d$ & 89.47B \\
\hline & $5 \% \mathrm{O}_{2}+5 \% \mathrm{CO}_{2}$ & $73.91 n$ & $79.01 \mathrm{~m}$ & 86.621 & $90.80 \mathrm{k}$ & $97.50 \mathrm{hi}$ & $108.27 b$ & 89.35B \\
\hline & $7 \% \mathrm{O}_{2}+5 \% \mathrm{CO}_{2}$ & $73.06 n$ & $78.20 \mathrm{~m}$ & 85.471 & $91.47 \mathrm{jk}$ & $98.95 \mathrm{gh}$ & $103.27 \mathrm{de}$ & $88.40 \mathrm{C}$ \\
\hline & SP (average) & $73.02 \mathrm{~F}$ & $80.19 \mathrm{E}$ & 87.51D & $94.86 \mathrm{C}$ & $100.68 \mathrm{~B}$ & $106.78 \mathrm{~A}$ & - \\
\hline \multicolumn{9}{|c|}{ Second season (2015) } \\
\hline \multirow{6}{*}{$\sum$} & Control (Net) & $57.43 q$ & $71.391 \mathrm{~m}$ & 77.06ij & $83.51 \mathrm{df}$ & $89.82 b$ & $97.01 \mathrm{a}$ & 79.37A \\
\hline & $3 \% \mathrm{O}_{2}+3 \% \mathrm{CO}_{2}$ & $58.69 q$ & 68.210 & $74.01 \mathrm{k}$ & $80.52 \mathrm{gh}$ & $87.01 \mathrm{c}$ & $95.48 \mathrm{a}$ & $77.32 \mathrm{~B}$ \\
\hline & $5 \% \mathrm{O}_{2}+3 \% \mathrm{CO}_{2}$ & $57.93 q$ & 68.66 no & $73.44 \mathrm{kl}$ & 79.13hi & $84.45 \mathrm{de}$ & $90.27 \mathrm{~b}$ & $75.64 \mathrm{C}$ \\
\hline & $5 \% \mathrm{O}_{2}+5 \% \mathrm{CO}_{2}$ & $59.37 \mathrm{q}$ & 67.390 & $73.81 \mathrm{k}$ & $81.80 \mathrm{fg}$ & $84.41 \mathrm{de}$ & $85.45 \mathrm{~cd}$ & $75.37 \mathrm{C}$ \\
\hline & $7 \% \mathrm{O}_{2}+5 \% \mathrm{CO}_{2}$ & $58.81 \mathrm{q}$ & $64.32 \mathrm{p}$ & $70.41 \mathrm{mn}$ & $76.74 j$ & $82.52 \mathrm{eg}$ & $89.93 b$ & 73.79D \\
\hline & SP (average) & $58.44 \mathrm{~F}$ & $67.99 \mathrm{E}$ & 73.74D & $80.34 \mathrm{C}$ & $85.64 \mathrm{~B}$ & $91.63 \mathrm{~A}$ & - \\
\hline
\end{tabular}

Values having the same alphabetical letter(s) did not significantly different according to LSD at 0.05 of probability AMA $=$ active modified atmosphere $. \mathrm{SP}=$ Storage period (day). 
recorded the lowest juice lycopene content $(88.40$ and $73.79 \mathrm{mg} / \mathrm{kg}$ in the first and second seasons, respectively). While, those treated by the other AMA treatments recorded in between values in both seasons without significant differences among them in most cases.

Moreover, lycopene content during shelf life showed continuous increase with the advance in storage period in both seasons. As such, the lowest values ( 73.02 and $58.44 \mathrm{mg} / \mathrm{kg}$ were recorded for zero sample in the first and second seasons, respectively).While, the highest values (106.78 and $91.63 \mathrm{mg} / \mathrm{kg}$ in the first and second seasons, respectively) were recorded at 35 days. Values of lycopene content during the other storing periods came in between.

In addition, the interaction was significant in the two seasons. As such, lycopene content reached the highest values (111.89 and 97.01 $\mathrm{mg} / \mathrm{kg}$ ) with control (net) at 35 days storing period. Whereas, the lowest values were recorded with zero time at all AMA treatments without significant differences between them. All other combinations gave in among values.

Generally, the results of the present work reveal that juice lycopene content was increased as cold storage period increased and the control treatment (net) raised lycopene content as compared with all tested AMA treatments during cold storage and after shelf life period.

The reduction in lycopene content with AMA treatments was in agreement with Yang et al. (1987). They reported that, higher $\mathrm{CO}_{2}$ and lower $\mathrm{O}_{2}$ inhibited further ripening by inhibition lycopene formation in packaged tomato fruits. Moreover, Kubo et al. (1989) stated that $\mathrm{CO}_{2}$ concentration affected color development of tomatoes by suppression of ethylene production. Javanmardi and Kubota (2006) reported that tomatoes which stored at room temperature showed significant increase in lycopene content as compared with those stored at low temperature. In addition, Vunnam et al. (2014) reported that MA storage, which maintained higher $\mathrm{CO}_{2}$ (11.3\%) and lower $\mathrm{O}_{2}$ (3.1\%) concentrations plausibly inhibited further ripening of already mature red cherry tomatoes.

\section{Total Soluble Solids (TSS Brix ${ }^{\circ}$ )}

\section{During cold storage periods}

Results in Table 6 reveal that the control treatment (net) recorded significantly highest juice TSS (4.00 and $4.08 \%$ in the first and second seasons, respectively). Whereas, fruits treated by $3 \% \mathrm{O}_{2}+3 \% \mathrm{CO}_{2}$ recorded the lowest TSS (3.41 and $3.52 \%$ in the first and second seasons, respectively) without significant differences with those treated by $5 \% \mathrm{O}_{2}+3 \%$ $\mathrm{CO}_{2}$ in both tested seasons. The other tested treatments recorded in between values.

However, TSS during cold storage was gradually increased with the advance in cold storage period in both tested seasons. As such, the lowest TSS (3.23 and 3.16\%) and highest TSS (4.06 and $4.20 \%)$ were recorded after zero time and at 35 days of cold storage period in both seasons, respectively. Values of TSS during the other storing periods came in between.

Moreover, the interaction between AMA treatments and cold storage periods was significant in both seasons and support the effect of each individual factor on TSS values. As such, the highest TSS values were recorded by the control $\times 28$ or at 35 days cold storage without significant differences between them in both seasons. While, the lowest TSS values were recorded at zero time without significant differences among them in both seasons.

\section{During shelf life periods}

Results in Table 6 clarify that the tested AMA treatments had significant effect on TSS\% in tomato fruit juice during shelf life in both tested seasons. As such, the uppermost values of TSS (4.19 and $4.44 \%$ in the first and second seasons, respectively) were detected in the control treatment without significant differences with those treated by $5 \% \mathrm{O}_{2}+5 \% \mathrm{CO}_{2}$ and $7 \%$ $\mathrm{O}_{2}+5 \% \mathrm{CO}_{2}$ in both tested seasons. In addition, the lowest values were observed by $3 \% \mathrm{O}_{2}+3 \%$ $\mathrm{CO}_{2}$ without significant differences with all tested gas combination in the first season and $5 \% \mathrm{O}_{2}+5 \% \mathrm{CO}_{2}$ and $5 \% \mathrm{O}_{2}+3 \% \mathrm{CO}_{2}$ in the second one.

Moreover, TSS showed continuous and sharp increase with the advance in cold storage 
Table 6. Effect of some active modified atmosphere (AMA) treatments on TSS (Brix ${ }^{\circ}$ ) of tomato fruits juice cv. Alisa during cold storage and shelf life periods during 2014 and 2015 seasons

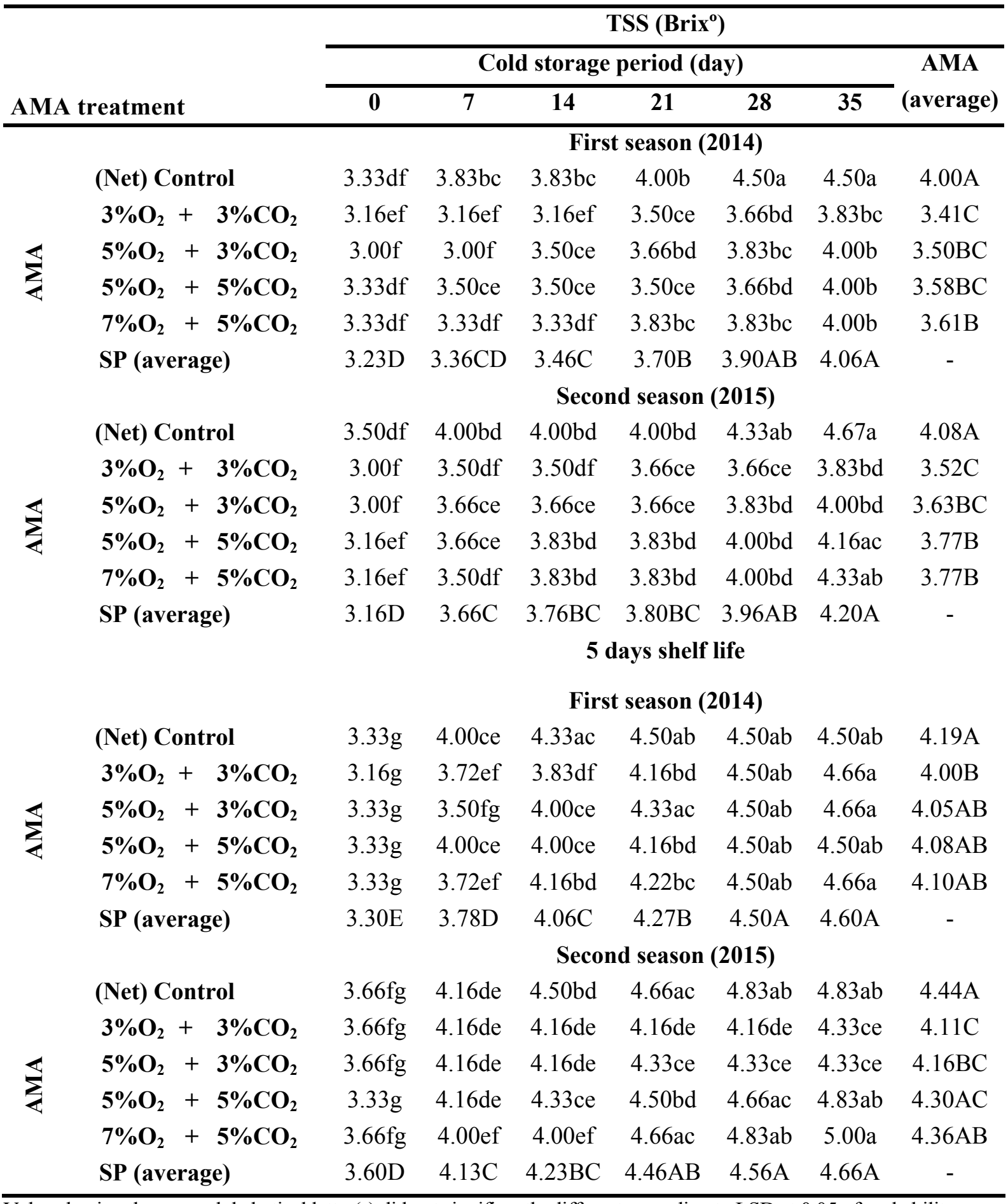

Values having the same alphabetical letter(s) did not significantly different according to LSD at 0.05 of probability $\mathrm{AMA}=$ active modified atmosphere, $\mathrm{SP}=$ Storage period (day). 
periods in both seasons. As such, the highest values of TSS (4.60 and $4.66 \%$ in the first and second seasons, respectively) were recorded at 35 days without significant differences with those at 28 days. Whereas, the least values of TSS $(3.30$ and $3.60 \%$ in the first and second seasons, respectively) were recorded at zero time. Values of TSS during the other storing periods came in between.

The interaction between AMA treatments and cold storage period was significant in both seasons and support the effect of each individual factor on TSS values.

Generally, AMA treatments decreased fruit TSS as compared with control, while TSS showed continuous and sharp increase with the advance in cold storage periods in both seasons.

These results agreed with those reported by Kays (1997) who reported that, changes in TSS contents were natural phenomenon occurred during ripening and correlated with hydrolytic changes in starch concentration during ripening in post harvest period. In tomatoes, conversion of starch to sugar is an important index of ripening. During ripening the degradation of cell wall polysaccharides (hemicellulose and pectins) occurred releasing of oligosaccharins. That known oligosaccharides with biological activity and potential intercellular signaling role (Albesshein and Darvill, 1985; Ryan and Farmer, 1991).

\section{REFERENCES}

Akbudak, B., N. Akbudak, V. Seniz and A. Eris (2007). Sequential treatments of hot water and modified atmosphere packaging in cherry tomatoes. J. Food Quality, 30 (6): 869-910.

Akbudak, B., N. Akbudak, V. Seniz and A. Eris (2012). Effect of pre-harvest harpin and modified atmosphere packaging on quality of cherry tomato cultivars "Alona" and “Cluster". British Food J., 114: 180-196.

Alam, T. and G. Goyal (2007). Packaging and storage of tomato puree and paste. Stewart Postharvest Rev., 3: 1-8.

Albesshein, P. and A. Darvill (1985). Oligosaccharins. Sci. Ame., 253: 44-50.
Anthon, G. and D.M. Barrett (2007). Standardization of a rapid spectrophotometric method for lycopene analysis. Acta Horticulturae 758 : X International Symposium on the Processing Tomato

AOAC (2000). Official Methods of Analysis $\left(16^{\text {th }}\right.$ Ed.). Washington, DC, USA: Association Official Analytical Chemists.

Batu, A. And A.K.Thompson (1998). Effects of modified atmosphere packaging on post harvest qualities of pink tomatoes. J. Agric. and Forestry, $22: 365-372$

Beecher, G.R. (1998). Nutrient content of tomatoes and tomato products. Exp. Biol. and Med., 218: 98-100.

Brandt, S., Z. Pék, É. Barna, A. Lugasi and L. Helyes (2006). Lycopene content and colour of ripening tomatoes as affected by environmental conditions. J. Sci. Food and Agric., 86: 568-572.

Buescher, R.W. (1979). Influence of carbondioxide on postharvest ripening and deterioration of tomatoes. J. Ame. Soc. Hort. Sci. 104, 4, 545-547.

Cantwell, M., X. Nie and G. Hong (2009). Impact of storage condition on grape tomato quality.6th ISHS Postharvest symposium, Antalya, Turkey.

Chapagain, B.P. and Z. Wiesman (2004). Effect of potassium magnesium chloride in the fertigation solution as partial source of potassium on growth, yield and quality of greenhouse tomato. Scientia Hort., 99: 279288.

Davies, J.N., G.E. Hobson and W. McGlasson (1981). The constituents of tomato fruit-the influence of environment, nutrition, and genotype. Critical Rev. Food Sci. and Nut., 15: 205-280.

Domínguez, I., M.T. Lafuente, P. HernándezMuñoz and R. Gavara (2016). Influence of modified atmosphere and ethylene levels on quality attributes of fresh tomatoes (Lycopersicon esculentum Mill.). Food Chem., 209: 211-219

Gharezi, M., N. Joshi and E. Sadeghian (2012). Effect of post harvest treatment on stored cherry tomatoes. J. Nut. Food Sci., 2 - 8. 
Grandillo, S., D. Zamir and S.D. Tanksley (1999). Genetic improvement of processing tomatoes: A 20 years perspective. Euphytica, 110: 85-97.

Grierson, D. and G.A. Tucker (1983). Timing of Ethylene and Polygalacturonase Synthesis in Relation to the Conrol of Tomato Fruit Ripening. Planta., 157: 174-179.

Hardenburg, R. E., A. E. Watada and C. Y. Wang, (1986). The commercial storage of fruits, vegetables, and florist and nursery stocks. Agric. Handbook, USDA.

Herner, R.C. (1987). High $\mathrm{CO}_{2}$ effects on plant organs. In Postharvest Physiology of Vegetables. (J. Weichmann. ed). Marcel Dekker Inc. New York, 239-253.

Javanmardi, J. and C. Kubota (2006). Variation of lycopene, antioxidant activity, total soluble solids and weight loss of tomato during postharvest storage. Postharvest Biol. and Technol., 41 (2): 151-155.

Kader, A.A. (1986). Biochemical and physiological basis for effects of controlled and modified atmospheres on fruits and vegetables. Food Technol., 40 (99-100): 102104.

Kays, S.J. (1997). Post-harvest physiology of perishable plant products. Van Nostrand Rein Hold Book, AVI Publishing Co. New York. 149-316.

Kubo, Y., A. Inaba and R. Nakamura (1989). Effects of high $\mathrm{CO}_{2}$ on respiration in various horticultural crops. J. Japan. Soc. Hort. Sci., 58 (3): 731-736.

Kumar, V., R. Shankar, and G. Kumar (2015). Strategies used for reducing postharvest losses in fruits and vegetables. Int. J. Sci. and Eng. Res., 6: 130-137.

Lee, S.K. and A.A. Kader (2000). Pre harvest and post harvest factors influencing vitamin $\mathrm{C}$ content of horticultural crops. Post harvest Biol. and Technol., 20 (3): 207-220.

Moneruzzaman, K.M., A.B. Hossain, W. Sani and M. Saifuddin (2008). Effect of stages of maturity and ripening conditions on the physical characteristics of tomato. Ame. J. Biochem. Biotech., 4:329-335
Moneruzzaman, K.M., A.B. Hossain, W. Sani, M. Saifuddin (2009). The effect of harvesting and storage conditions on the post harvest quality of tomato (Solanum esculentum Mill) cv. Roma VF. Aust. J. Food Crops, 3: 113121.

Ryan, C.A. and E. Farmer (1991). Oligosaccharide signals in plants: a current assessment. Annu. Rev.Plant Physiol. Plant. Mol. Biol., 42: 651674.

Risse, L., W. Miller and S. Ben-Yehoshua (1985). Weight loss, firmness, colour and decay development of individually filmwrapped tomatoes. Tropical Sci., 25 : 117-121.

Rosa, S. (2006). Postharvest management of fruit and vegetables in the Asia-Pacific region/Asian Productivity Organization. Food and Agric. Organ. (FAO).

Saeed, A.F., S.N. Khan, A. Sarwar and J.J. Tahira (2010). Effect of packing materials on storage of tomato. Mycopath, 8 (2): 85-89.

Sánchez-Moreno, C., L. Plaza, B. de Ancos, M.P. Cano, (2006). Impact of high-pressure and traditional thermal processing of tomato purée on carotenoids, vitamin $\mathrm{C}$ and antioxidant activity. J. Sci. Food Agric., 86: 171-179.

Shama, G. and P. Alderson (2005). UV hormesis in fruits: a concept ripe for commercialization. Trends Food Sci. Technol., 16: 128-136

Snedecor, G.W. and W.G. Cochran (1980). Statistical Methods. Iowa, USA.

Spalding, D.H. (1980). Control of Alternaria rot of tomatoes by postharvest application of imazalil. Plant Disease, 64 : 169-171.

Tasdelen, O. and L. Bayindirli (1998). Controlled atmosphere storage and edible coating effects on storage life and quality of tomatoes. J Food Proc. Preserv, 22: 303-320.

Themman, A.P.N., G. Tucker and D. Grierson (1982). Degradation of isolated tomato cell walls by purified polygalacturonase in vitro. Plant Physiol., 69: 122-124.

Ullah, J. (2009). Storage of fresh tomatoes to dertermine the level of $\left(\mathrm{CaCl}_{2}\right)$ coating and optimum temperature for extended shelf life, Asian Inst. Technol. Bangkok, Thailand. 
USDA (1991). United states standards for grades of fresh tomatoes. http:// www. ams. usda. gov/ AMSv1.0/ getfile? dDoc Name= STELPRDC5 050331

Vunnam, R., A. Hussain, G. Nair, R. Bandla, Y. Gariepy, D.J. Donnelly, S. Kubow and G.S.V. Raghavan (2014). Physico-chemical changes in tomato with modified atmosphere storage and UV treatment. J. Food Sci. Technol., 51 (9): 2106 -2112.

Yang, C.C., P. Brennan, M.S. Chinnan and R.L. Shewfelt (1987). Characterization of tomatoes ripening process as influenced by individual seal-packaging and temperature. J. Food Quality, 10: 21-33.

\section{تأثيــر بعض معامـلات الجو الهوائى المعدل على جودة ثمار الطماطم أثناء فترة التخـزين المبرد

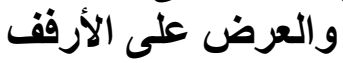

عاصم أحمد سيد أحمد حسن - حامد محمد الهادى عريشة ـ عبد الله برديسى أحمد- صبرين خلف الله إبراهيم

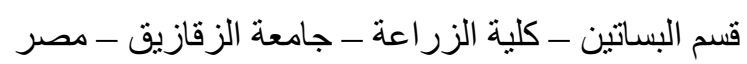

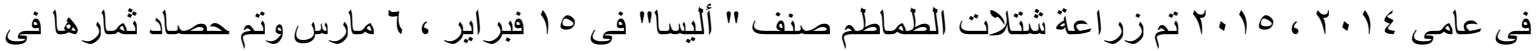

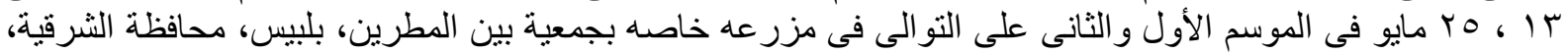

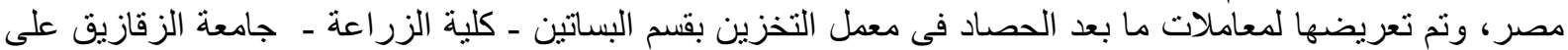

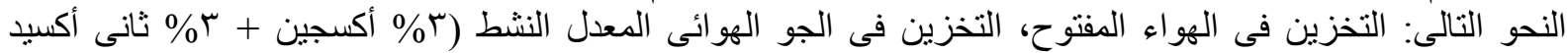

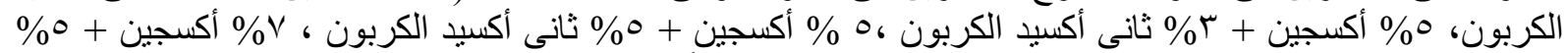

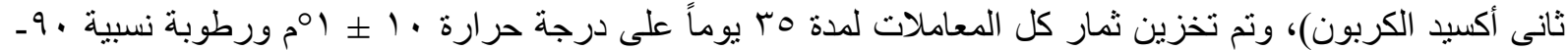

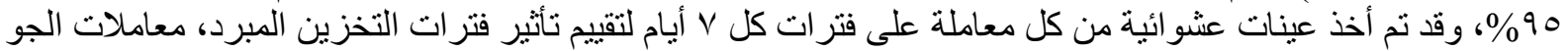

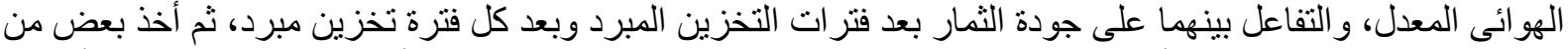

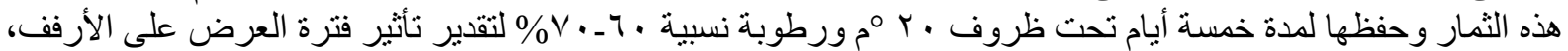

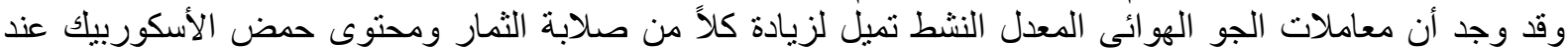

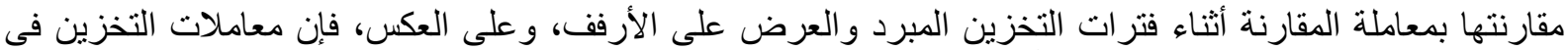

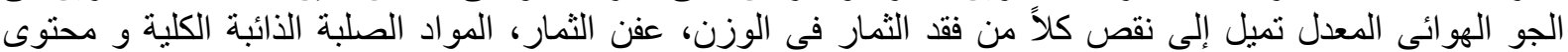

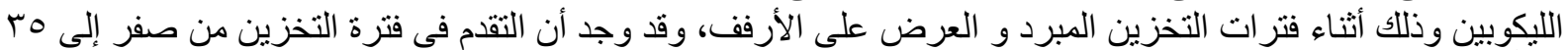

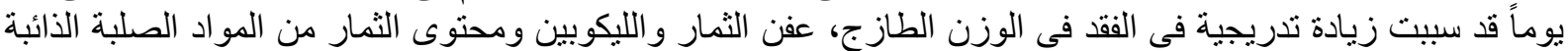

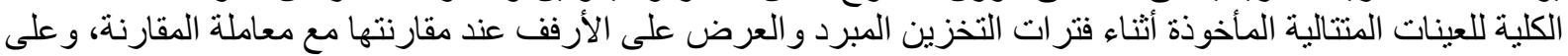

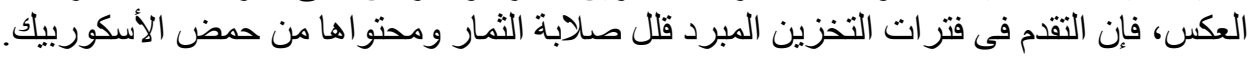

